\title{
The effects of hydrostatic pressure on ribosome conformation in Escherichia coli: an in vivo study using differential scanning calorimetry
}

\author{
Gordon W. Niven, ${ }^{1}$ Christopher A. Miles ${ }^{2}$ and Bernard M. Mackey'
}

Author for correspondence: Gordon Niven. Tel: +44118935 7000. Fax: +441189267917.

e-mail: gordon.niven@bbsrc.ac.uk

1 Institute of Food Research Reading Laboratory, Earley Gate, Whiteknights Road, Reading RG6 6BZ, UK

2 University of Bristol School of Clinical Veterinary Science, Churchill Building Langford, Bristol BS40 5DU, UK

\begin{abstract}
Differential scanning calorimetry of whole Escherichia coli cells allowed the detection in vivo of changes in ribosome conformation. This enabled for the first time an analysis of the effects of high hydrostatic pressures on ribosomes in living cells. A correlation was observed between loss of cell viability and decrease in ribosome-associated enthalpy in cells subjected to pressures of 50-250 MPa for $20 \mathrm{~min}$. Cell death and ribosome damage were therefore closely related phenomena. In pressure-treated cells, the thermogram peak temperatures decreased, suggesting that the remaining ribosomes had adopted a less stable conformation. During subsequent incubation of the cultures at $37{ }^{\circ} \mathrm{C}$, peak temperatures and enthalpies gradually increased over a period of $5 \mathrm{~h}$. This change in ribosome conformation had no apparent effect on cell survival, as viability continued to decrease. The addition of $5 \mathrm{mM} \mathrm{MgCl}$ before pressure treatment of cells prevented the reduction in stability of surviving ribosomes but had no effect on the initial loss of enthalpy or on cell viability.
\end{abstract}

Keywords: ribosome, differential scanning calorimetry, hydrostatic pressure, barophysiology

\section{INTRODUCTION}

The effects of high hydrostatic pressures on living systems have long been of interest due to the survival of organisms in the deep-sea environment, where pressures can reach $110 \mathrm{MPa}$ (Jannasch \& Taylor, 1984; Yayanos, 1995). More recently, the potential of high pressure as a means of food preservation has been recognized. It has been suggested this type of processing has the advantage over more usual heat treatments that undesirable chemical changes of food components are reduced (Farr, 1990; Johnston, 1994). It is therefore of some significance to both these fields to determine the effects of high pressures on biological systems. In particular, knowledge of the biochemical processes or structural components with the greatest sensitivity to elevated pressures would be of value in understanding cell death and adaptation.

Protein synthesis is known to be one of the most pressure-sensitive cell activities (Landau, 1967). In

Abbreviations: DSC, differential scanning calorimetry; RAE, ribosomeassociated enthalpy.
Escherichia coli cell-free systems, protein synthesis is completely inhibited at $68 \mathrm{MPa}$, but the inhibition is reversible after pressure release (Schwartz \& Landau, 1972; Smith et al., 1975). It has been demonstrated using light-scattering analysis that ribosomes dissociate in vitro under high pressure (Schultz et al., 1976; Gross \& Jaenicke, 1990; Gross et al., 1993). This has led to the suggestion that ribosome dissociation may be one of the principal causes of growth inhibition at high pressures. Gross et al. (1993) investigated the effects of high pressure on elongation-cycle intermediates and observed ribosome dissociation starting at 40-60 MPa. This work suggested that the post-translational complex is the most pressure-sensitive component. Exposure to higher pressures results in cell death (Hoover et al., 1989; Cheftel, 1995), which implies that critical cellular activities or processes have been irreversibly damaged. At the present time, little is known about the irreversible effects of high pressure on the protein synthesis system or the mechanisms of cell death in pressure-treated bacteria.

Almost all that is known about ribosome structure and function has been determined by the analysis of ribo- 
somes and their components after their isolation from living cells (Green \& Noller, 1997). In previous studies concerning the effects of high pressure on ribosomes, the analyses have been carried out in vitro. It is known that ribosome conformation is highly dependent on the chemical environment (Hapke \& Noll, 1976; Noll \& Noll, 1976), so such analyses have the disadvantage that the chemical conditions inside the cell after being subject to extreme stress may not be known. In addition, the isolation of purified ribosomal subunits involves ultracentrifugation for long periods, which can cause artefacts due to the high hydrostatic pressures involved (Hauge, 1971; Spirin, 1971). More recently, flow fieldflow fractionation has been applied to ribosome analysis (Nilsson et al., 1996, 1997). This enables more rapid isolation of ribosomal subunits without the application of high hydrostatic pressures, but the analyses are carried out in vitro after the preparation of cell-free extracts. In order to overcome these limitations, we have sought to develop a technique that enables the analysis of ribosome conformation in vivo.

Differential scanning calorimetry (DSC) enables the detection of thermal events in samples as they are heated. It has previously been applied to bacterial cultures, most commonly to analyse the influence of temperature on the denaturation of structural components (Miles et al., 1986; Lepock et al., 1990; Anderson et al., 1991). Mackey et al. (1991) partially characterized the main thermogram peaks obtained in E. coli using whole cells, the most prominent components being associated with ribosome denaturation. The maximum growth temperatures of different species of bacteria have been correlated with ribosome $T_{\mathrm{m}}$ values, suggesting a relationship between ribosome stability and thermal resistance (Campbell \& Pace, 1968; Lepock et al., 1990; Mackey et al., 1993; Mohácsi-Farkas et al., 1994).

Studies of ribosome behaviour and the thermal denaturation of cell components in vitro suggest that ribosomes may be particularly sensitive to conformational change when subject to physical stresses. It is therefore possible that inactivation of $E$. coli by high pressure could also involve ribosome denaturation. In this study, we therefore used DSC as a method of detecting changes in ribosome conformation in vivo.

\section{METHODS}

Cell culture conditions. Escherichia coli NCTC 8164 was grown in Tryptone Soya Broth at $37^{\circ} \mathrm{C}$. This strain lacks ribonuclease I and was used in previous DSC studies of thermal resistance (Mackey et al., 1991). Stationary-phase cultures were used for all experiments. These were obtained using a $1 \%(\mathrm{v} / \mathrm{v})$ inoculum of stationary-phase cells and incubating cultures for $16 \mathrm{~h}$. Concentrations of viable cells were estimated following serial dilution in Maximum Recovery Diluent and plating $100 \mu \mathrm{l}$ samples on Tryptone Soya Agar. Plates were incubated for $24 \mathrm{~h}$ at $37^{\circ} \mathrm{C}$ before counting $50-500$ colonies. The data presented are the means of triplicate determinations; their standard deviations averaged $14 \%$ of the mean values. All media were supplied by Oxoid. Growth curves were obtained by measuring the $\mathrm{OD}_{600}$ of cultures using a Perkin-Elmer Lambda 15 spectrophotometer and $1 \mathrm{~cm}$ pathlength cuvettes. Lag times were determined by means of the curve-fitting model of Baranyi \& Roberts (1994), using our in-house program DMFit, written by J. Baranyi. Cultures were inoculated and incubated as above.

High-pressure treatment. Samples of whole cell culture $(10-100 \mathrm{ml})$ were placed in heat-sealed plastic stomacher bags and subjected to hydrostatic pressure using a Stansted Mark II Enhanced Mini Food Lab pressure rig (model S-FL-850-9-W, Stansted Fluid Power). All treatments were carried out at room temperature. Pressure-induced temperature changes during compression and decompression were limited to $\pm 10^{\circ} \mathrm{C}$, measured with a thermocouple inserted into the pressure-transmitting fluid.

DSC. DSC thermograms were obtained using a Perkin Elmer DSC 7 differential scanning calorimeter. Cells were concentrated by centrifuging $1.5 \mathrm{ml}$ samples of culture at $12000 \mathrm{~g}$ for $4 \mathrm{~min}$ and resuspending the pellet in a minimum volume of the supernatant. The resulting suspensions (maximum volume $20 \mu \mathrm{l}$ ) were sealed in pre-weighed volatile sample aluminium DSC pans. Thermograms were run from 40 to $100^{\circ} \mathrm{C}$ using a

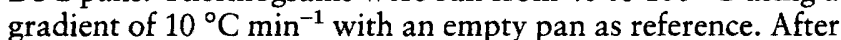
the initial analysis, all samples were cooled to $40^{\circ} \mathrm{C}$ and the temperature scan was rerun. The second thermogram was subtracted from the first to remove consistent baseline fluctuations present in all analyses. This also removed a broad shallow peak at $55-80^{\circ} \mathrm{C}$ which corresponded to reversible RNA melting (Mackey et al., 1991). All reported data therefore refer only to irreversible thermal events. After analysis, pans were pierced and the samples were dried in an oven at $80^{\circ} \mathrm{C}$ for $24 \mathrm{~h}$ before determining the dry weight of cells (approx. $1 \mathrm{mg}$ ). The enthalpies of thermal events detected in the DSC thermograms were calculated as the area under thermogram peaks, normalized to the dry weight of sample. Due to the time dependency of pressure-induced changes in the DSC thermograms, it was not possible to carry out replicate analyses of data presented as time courses, other than of non-pressuretreated controls. The data reported are therefore the results of single determinations, although the results presented have been reproduced in several replicate experiments. Other peak temperatures and enthalpies were determined in triplicate. The standard deviations of enthalpies calculated from peak areas were approximately $5 \%$ of mean values for peak $m$ and $15 \%$ for peak $n$. The standard deviations of mean peak temperature determinations were $0.3^{\circ} \mathrm{C}$.

\section{RESULTS}

When DSC analyses of whole cell cultures of stationaryphase $E$. coli were carried out, endothermic events were detected in the area $55-90^{\circ} \mathrm{C}$ (Fig. 1). These were previously identified by Mackey et al. (1991) as being associated with ribosome components. The two most prominent peaks are here designated $m$ and $n$ according to their notation. Peak $m$ can be divided into two main regions : the largest component at approximately $69^{\circ} \mathrm{C}$, and a shoulder at approximately $62-64^{\circ} \mathrm{C}$. As these were rarely resolved, they were combined in determinations of enthalpy. Peak $n$ was located at $79-80^{\circ} \mathrm{C}$ and corresponded to $5-10 \%$ of the total ribosome-associated enthalpy (RAE) of approximately $4 \mathrm{~J}$ ( $\mathrm{g}$ dry weight $)^{\mathbf{1}}$.

Fig. 1 also shows the DSC thermograms of cell cultures that were analysed immediately after being subjected to 


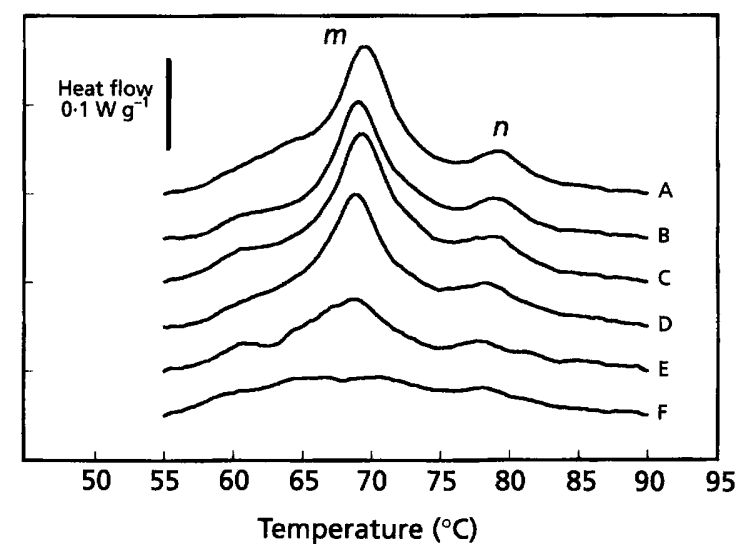

Fig. 1. DSC thermograms of stationary-phase cultures before pressure treatment (A), and after pressure treatment for $20 \mathrm{~min}$ at $50 \mathrm{MPa}$ (B), $100 \mathrm{MPa}$ (C), $150 \mathrm{MPa}$ (D), $200 \mathrm{MPa}$ (E) and $250 \mathrm{MPa}$ (F). The main thermogram features are labelled $m$ and $n$.

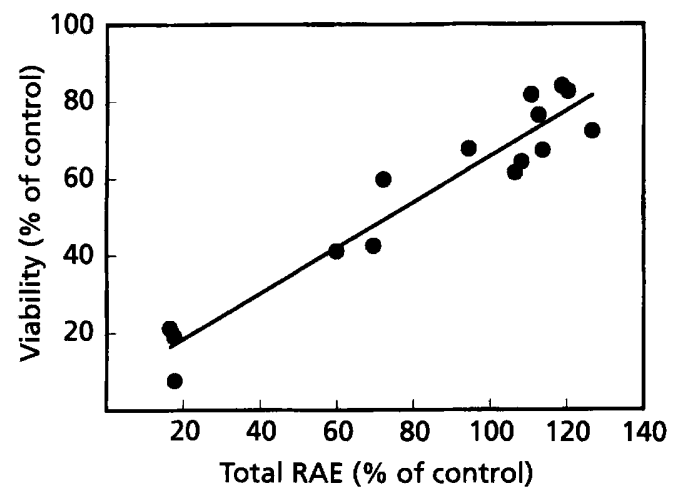

Fig. 2. Relationship between the total RAE and cell viability in pressure-treated cells. Cultures were subjected to various pressures (50-250 MPa) for $20 \mathrm{~min}$, and viability determinations and DSC analyses were carried out immediately after decompression. The mean control values were $5 \times 10^{8}$ c.f.u. $\mathrm{ml}^{-1}$ for viability and $3.51 \mathrm{~J} \mathrm{~g}^{-1}$ for enthalpy.

various hydrostatic pressures for $20 \mathrm{~min}$. The reductions in the total peak areas indicated an overall reduction in RAE. This suggested that the number of intact, native ribosomes decreased after pressure treatment. In addition, the peak temperatures of the thermograms of pressure-treated cells were lower, which indicated that the ribosomes that remained had adopted a less stable conformation. These effects were more pronounced at higher pressures, and at $250 \mathrm{MPa}$ no easily distinguishable thermogram peaks remained.

Total RAE and cell viability were determined for pressure-treated cultures immediately after decompression (Fig. 2). Pressure treatments of 50 and $100 \mathrm{MPa}$ for $20 \mathrm{~min}$ resulted in small reductions in viability $(25 \%)$, but caused $20 \%$ increases in RAE. At higher pressures, a direct correlation was observed between the

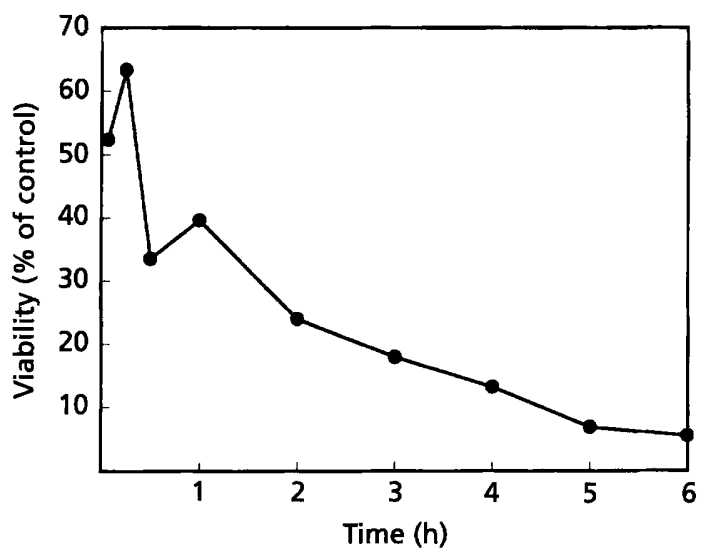

Fig. 3. Cell viability of cultures during incubation at $37^{\circ} \mathrm{C}$ after pressure treatment at $200 \mathrm{MPa}$ for $20 \mathrm{~min}$. The $100 \%$ value is the viability before pressure treatment, which was approximately $8 \times 10^{8}$ c.f.u. $\mathrm{ml}^{-1}$.

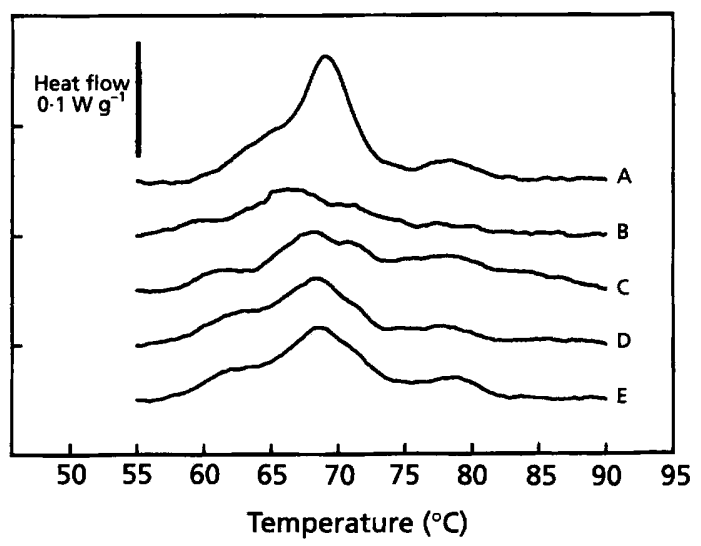

Fig. 4. DSC thermograms of stationary-phase cultures after pressure treatment at $200 \mathrm{MPa}$ for $20 \mathrm{~min}$ followed by incubation at $37^{\circ} \mathrm{C}$ for $4 \mathrm{~min}(\mathrm{~B}), 1 \mathrm{~h}(\mathrm{C}), 3 \mathrm{~h}$ (D) and $5 \mathrm{~h}$ (E). Trace $A$ is the thermogram obtained before pressure treatment.

remaining cell viability and RAE. Viability was reduced to $48 \%$ and $16 \%$ of control values after treatments of $200 \mathrm{MPa}$ and $250 \mathrm{MPa}$, respectively. It was not possible to extend this study to pressures higher than $250 \mathrm{MPa}$. Such pressures resulted in the reduction of viability by more than 1 log unit and total enthalpy could only be accurately determined on a linear scale.

Cell viability continued to decrease during the period after the pressure had been released. On incubation at $37^{\circ} \mathrm{C}$ of a culture previously subjected to a pressure of $200 \mathrm{MPa}$ for $20 \mathrm{~min}$, viability decreased from $52 \%$ immediately after pressure treatment to $6 \%$ of control values over a period of $6 \mathrm{~h}$ (Fig. 3). Further evidence of progressive cell damage after pressure treatment was obtained from the growth characteristics of cultures inoculated with cells that had been subjected to high hydrostatic pressures. The lag phase determined in 

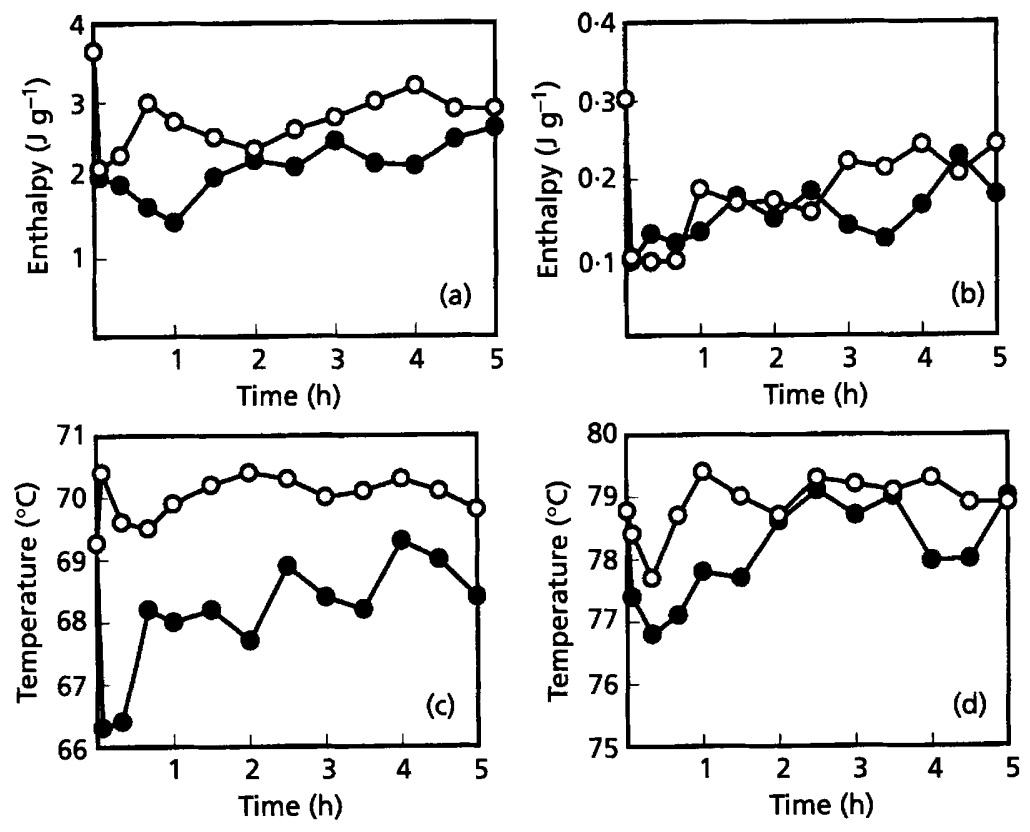

Fig. 5. The enthalpies (a, b) and temperatures $(c, d)$ of thermogram peaks $m$ $(a, c)$ and $n(b, d)$ after pressure treatment at $200 \mathrm{MPa}$ for $20 \mathrm{~min}$, followed by incubation at $37^{\circ} \mathrm{C}$. Data are shown for cultures pressure-treated and incubated in the presence $(O)$ and absence $(0)$ of $5 \mathrm{mM}$ $\mathrm{MgCl}_{2}$.

liquid culture at $37^{\circ} \mathrm{C}$ using a $1 \%(\mathrm{v} / \mathrm{v})$ inoculum of stationary-phase cells was approximately $1.0 \mathrm{~h}$. The lag increased to $2.8 \mathrm{~h}$ when the inoculum consisted of cells immediately after pressure treatment, and to $4.5 \mathrm{~h}$ when cells were inoculated $2 \mathrm{~h}$ after pressure treatment (data not shown). The increased lag phase could not be attributed solely to lower starting concentrations of viable cells as this effect was not reproduced when nonpressure-treated inocula were diluted to levels equivalent to the cell density after pressure treatment.

Further changes in ribosome conformation were observed during post-pressure incubation. Fig. 4 shows the DSC thermograms of non-pressure-treated cells, cells immediately after pressurization at $200 \mathrm{MPa}$ for $20 \mathrm{~min}$, and cells incubated at $37^{\circ} \mathrm{C}$ for different times after pressure treatment. Following the initial reduction in peak areas and temperatures after pressure treatment, the total RAE and peak temperatures increased during the subsequent incubation period. In some thermograms, an additional peak at approximately $71-72{ }^{\circ} \mathrm{C}$ was observed. This may indicate that peak $m$ consists of additional components, or it could reflect a change in the interactions of ribosome components after pressure treatment.

The effects of pressure treatment and subsequent incubation of cells on DSC thermograms are shown in more detail in Fig. 5, in which the effects of pressure treatment and subsequent incubation in the presence and absence of $5 \mathrm{mM} \mathrm{MgCl} 2$ are compared. The enthalpy of peak $m$ was reduced to $56 \%$ that of nonpressure-treated controls when measured immediately after decompression. It gradually increased to $73 \%$ of control values $5 \mathrm{~h}$ after pressure treatment. Peak $n$ enthalpy was initially reduced to $31 \%$ of control values and increased to $59 \%$ after $5 \mathrm{~h}$ incubation at $37^{\circ} \mathrm{C}$. The addition of $5 \mathrm{mM} \mathrm{MgCl}$ to the cell suspension before

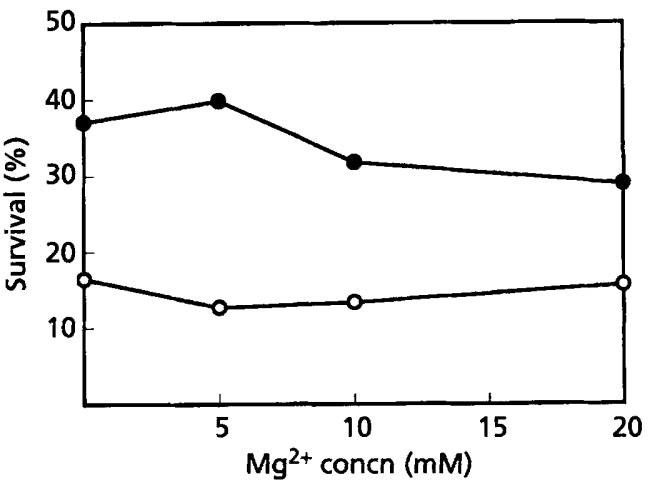

Fig. 6. Viability of cultures after pressure treatment and incubation in the presence of various concentrations of $\mathrm{MgCl}_{2}$. Cultures were pressurised at $200 \mathrm{MPa}$ for $20 \mathrm{~min}$ and viability was determined immediately after decompression (O) and after $5 \mathrm{~h}$ incubation at $37^{\circ} \mathrm{C}(\mathrm{O})$. Values are expressed as a percentage of the viability before pressure treatment, which was approximately $8 \times 10^{8}$ c.f.u. $\mathrm{ml}^{-1}$.

pressure treatment had little effect on the initial reduction in peak enthalpies. During the subsequent incubation period, however, the enthalpies measured for peak $m$ were on average $30 \%$ higher in the presence of $\mathrm{MgCl}_{2}$.

Immediately after pressure treatment in the absence of additional $\mathrm{MgCl}_{2}$, the peak temperatures of $m$ and $n$ were reduced by $3.0^{\circ} \mathrm{C}$ and $1.4^{\circ} \mathrm{C}$, respectively. Both increased gradually during the following $5 \mathrm{~h}$ incubation at $37^{\circ} \mathrm{C}$. Peak $m$ had returned to the control value by approximately $4 \mathrm{~h}$, and peak $n$ by approximately $2 \mathrm{~h}$. When cells were pressure treated in the presence of $5 \mathrm{mM} \mathrm{MgCl}$, the temperature of peak $m$ did not decrease, but rather was elevated by $1.1^{\circ} \mathrm{C}$ and remained 
on average $0.8^{\circ} \mathrm{C}$ higher than the starting value throughout the subsequent incubation period. The temperature of peak $n$ fell by $1.1^{\circ} \mathrm{C} 20$ min after pressure treatment, but rose to the initial control value after $40 \mathrm{~min}$.

Although the presence of elevated levels of $\mathrm{Mg}^{2+}$ during pressure treatment appeared to influence ribosome conformation, it did not affect the initial loss of RAE when measured immediately after decompression. Also, there was no evidence that it affected cell survival. Cells were pressure treated in the presence of various concentrations of $\mathrm{MgCl}_{2}$ and viability was determined immediately after pressure treatment and after $5 \mathrm{~h}$ incubation of pressure-treated cells at $37^{\circ} \mathrm{C}$ (Fig. 6). No significant difference in viability was observed in either case with up to $20 \mathrm{mM} \mathrm{MgCl}_{2}$.

\section{DISCUSSION}

The ribosome-associated components of the DSC thermogram were identified by Mackey et al. (1991), who observed peaks $m$ and $n$ in samples of whole cell culture, cell extracts and isolated ribosome preparations. No peaks were detected in this region of the thermogram after the removal of the ribosomes from cell extracts, although thermal events not associated with ribosomes were detected after further concentration of the samples. It can therefore be concluded that the thermal events investigated in the current study were primarily related to ribosomes and that other cell components made only a negligible contribution.

Mackey et al. (1991) observed multi-component peaks in analyses of isolated ribosome components. The major components were located at $66^{\circ} \mathrm{C}$ and $71^{\circ} \mathrm{C}$ for $30 \mathrm{~S}$ subunits, and at $74^{\circ} \mathrm{C}$ and $81^{\circ} \mathrm{C}$ for $50 \mathrm{~S}$ subunits. This compared with peaks at $68^{\circ} \mathrm{C}, 76^{\circ} \mathrm{C}$ and $82{ }^{\circ} \mathrm{C}$ for isolated $70 \mathrm{~S}$ units. The major peaks identified in our analyses of whole cell cultures were at $62-64^{\circ} \mathrm{C}, 69^{\circ} \mathrm{C}$, $71-72^{\circ} \mathrm{C}$ and $79-80^{\circ} \mathrm{C}$. The third of these was only observed in some samples after pressure treatment and was possibly obscured in control samples. The thermogram peak temperatures determined using isolated ribosome subunits are dependent on the composition of the media used. In addition, association of subunits appears to cause changes in the peak temperatures relative to isolated subunits. However, we can tentatively conclude that the in vivo DSC ribosome thermogram consisted of at least four main elements. The peak designated $m$ in the current study was a combination of three components. The shoulder at $62-64^{\circ} \mathrm{C}$ was associated with the $30 \mathrm{~S}$ subunit, and the main peak at $69^{\circ} \mathrm{C}$ was composed of a lower temperature $30 \mathrm{~S}$ component and a higher temperature $50 \mathrm{~S}$ component. The latter component was probably the smaller of the two and was not resolved as an individual thermogram peak unless the $30 \mathrm{~S}$ component was shifted to a lower temperature after pressure treatment. Peak $n$ was associated with the 50 S subunit.

The above peak designations are consistent with previous observations that the $30 \mathrm{~S}$ ribosome subunit is the more temperature sensitive. Correlations between the temperature at which heated bacteria start to die and the temperature of ribosome-associated DSC thermogram events have been observed (Campbell \& Pace, 1968; Lepock et al., 1990; Mackey et al., 1993; MohácsiFarkas et al., 1994). This strongly suggests that the temperatures of ribosome-associated DSC events are an indication of ribosome stability, and also that ribosome damage may be an important factor causing cell death in cells undergoing physical stress.

The direct relationship between total RAE and cell viability ran from $120 \%$ of control values for samples treated at $50 \mathrm{MPa}$ to about $20 \%$ for samples treated at $250 \mathrm{MPa}$. Thus, mild pressure treatment apparently caused a small initial increase in RAE although viability decreased by approximately $20 \%$. There are several possible explanations for this. The initial increase in enthalpy could have been caused by a stress response resulting in the association of protein with the ribosome. Alternatively, the apparent increase may have been artefactual, caused by physical changes during pressurization. For example, leakage of material from cells during pressure treatment could have resulted in a loss of material when cells were subsequently centrifuged and resuspended for DSC analysis. The apparent increase in RAE could therefore have resulted from a decrease in the dry weight per cell rather than a real increase in RAE. In either case, the effect would be to increase slightly the total RAE for all pressure-treated cells. We have to conclude that there is some uncertainty about the changes in RAE and viability that occurred during very mild pressure treatment. However, the results do show convincingly that, over the wider range, loss of RAE was associated with loss of viability. The simplest explanation for this correlation is that ribosome denaturation was a direct cause of cell death. The further decline in viability that occurred after decompression and incubation at ambient pressure was not associated with a further decrease in RAE, so other factors may cause death in pressure-damaged cells. The nature of these later events is not known but could include the triggering of degradative processes in cells with damaged membranes.

It may be expected that the death of an individual cell would occur when the number of functional ribosomes dropped below a critical threshold level beyond which the cell could not recover. The majority of cells would have ribosome numbers well in excess of this level. Therefore, if pressure-induced damage was distributed evenly throughout the total ribosome population, only a small number of cells with ribosome numbers close to the threshold level would be killed by a small decrease in the total RAE. The slope of the viability versus enthalpy curve would thus be shallow. The slope would increase at higher pressures when the loss of enthalpy became sufficient to reduce the ribosome numbers to the threshold level in the majority of cells. If still higher pressures were applied, further decreases in enthalpy would not result in marked loss of viability, as the majority of cells would already have ribosome numbers 
below the threshold. It is clear from this model that the viability versus enthalpy curve would be sigmoidal if damage was evenly distributed throughout the ribosome population. The observed curve was not this shape, suggesting that this was not the case. A linear response would be consistent with an 'all-or-nothing' model in which all of the ribosomes of killed cells were destroyed while those of surviving cells remained largely unaffected. This model suggests that a catastrophic event affecting individual cells triggered the destruction of the majority of ribosomes. This would inevitably result in cell death. A mixed population of ribosome-replete and ribosome-deficient cells has previously been observed by electron microscopy of Salmonella thompson cultures pressure treated at $250 \mathrm{MPa}$ for $10 \mathrm{~min}$ (Mackey et al., 1994).

The changes in ribosome conformation after pressure treatment demonstrated that the ribosomes of surviving cells were also affected by pressure treatment. Some indication of the nature of these events may be gained from the observed effects of pressure treatment in the presence and absence of $\mathrm{MgCl}_{2}$. It is well established that $\mathrm{Mg}^{2+}$ has a stabilizing effect on ribosome structure in vitro (Noll \& Noll, 1976). Elevated levels of extracellular $\mathrm{Mg}^{2+}$ appeared to influence ribosome conformation in vivo only after pressure treatment, when they limited the pressure-induced destabilization of surviving ribosomes. A possible explanation is that pressure treatment rendered the cells permeable to $\mathrm{Mg}^{2+}$. Membrane permeabilization after pressure treatment of $E$. coli has previously been demonstrated by leakage of UVabsorbing material and increased fluorescence of acridine-orange-stained cells (Shigehisa et al., 1991). In the absence of elevated levels of extracellular $\mathrm{Mg}^{2+}$, pressure-induced damage to the cell membrane may have resulted in leakage of $\mathrm{Mg}^{2+}$ from the cell and therefore destabilization of ribosome structure.

This suggestion is analogous to the situation reported previously for heat-damaged bacterial cells. Ribosome damage resulting from sublethal heating of Staphylococcus aureus (Hurst \& Hughes, 1978) and Salmonella typhimurium (Tolker-Nielsen \& Molin, 1996) was caused by loss of $\mathrm{Mg}^{2+}$ from the cell, rather than the direct effect of heat on the ribosomes per se. At relatively mild temperatures $\left(<50^{\circ} \mathrm{C}\right)$ selective destruction of the $30 \mathrm{~S}$ ribosome subunit is observed, which has been attributed to destabilization of the ribosomes by loss of $\mathrm{Mg}^{2+}$ (Tomlins \& Ordal, 1976; Hurst, 1984). This damage is reversible and cells can recover under suitable conditions. At higher temperatures irreversible destruction of 30 S subunits is lethal (Anderson et al., 1991; Mackey et al., 1993).

Bacteria subjected to high hydrostatic pressures can undergo an adaptive response. It has been demonstrated that pressure-treated cells synthesize pressure-induced proteins, some of which are also produced in response to heat or cold shock (Welch et al., 1993). Other potentially adaptive changes in protein expression have been observed (Jaenicke et al., 1988; Kato et al., 1994;
Nakashima et al., 1995). In all of these reports, the pressures used have been sublethal (30-55 MPa). As the production of stress-response proteins requires a functional protein synthesis system, it may be that the ribosome damage occurring at the higher pressures applied in the current study limited the stress response and therefore the ability of the cells to survive. If most of the surviving ribosomes were located in viable cells, it remains possible that some of the changes observed in ribosome conformation during post-pressure incubation were the result of a stress-response mechanism. Some of the pressure-induced proteins observed by Welch et al. (1993) were identified as ribosomal proteins, and heat shock has been shown to increase ribosome stability in Listeria (Stephens \& Jones, 1993). It has also been suggested that the ribosomes themselves function as indicators of stress in bacterial cells through changes in the translational capacity of the cell (VanBogelen \& Neidhardt, 1990).

This study has demonstrated the potential of DSC as a method of in vivo ribosome analysis. In has enabled for the first time observations of ribosome conformation and damage in living cells after severe physical stress. The results obtained here suggest that the ribosome may be a critical target of lethal as well as growth-inhibitory effects of high pressure on bacteria. Greater insights into the conformation of ribosomes in vivo will be gained when the DSC thermal events can be attributed more closely to specific ribosome interactions, and further work aimed at the characterization of these events is in progress.

\section{REFERENCES}

Anderson, W. A., Hedges, N. D., Jones, M. V. \& Cole, M. B. (1991). Thermal inactivation of Listeria monocytogenes studied by differential scanning calorimetry. J Gen Microbiol 137, 14191424.

Baranyi, J. \& Roberts, T. A. (1994). A dynamic approach to predicting bacterial growth in food. Int J Food Microbiol 23, 277-294.

Campbell, L. L. \& Pace, B. (1968). Physiology of growth at high temperatures. J Appl Bacteriol 31, 24-38.

Cheftel, J.-C. (1995). Hautes pressions, inactivation microbienne et conservation des aliments. C R Acad Agric Fr 81, 13-38.

Farr, D. (1990). High pressure technology in the food industry. Trends Food Sci Technol 1, 14-16.

Green, R. \& Noller, H. F. (1997). Ribosomes and translation. Annu Rev Biochem 66, 679-716.

Gross, M. \& Jaenicke, R. (1990). Pressure-induced dissociation of tight couple ribosomes. FEBS Lett 267, 239-241.

Gross, M., Lehle, K., Jaenicke, R. \& Nierhaus, K. H. (1993). Pressure-induced dissociation of ribosomes and elongation cycle intermediates. Stabilizing conditions and identification of the most sensitive functional state. Eur J Biochem 218, 463-468.

Hapke, B. \& Noll, H. (1976). Structural dynamics of bacterial ribosomes. IV. Classification of ribosomes by subunit interaction. J Mol Biol 105, 97-109.

Hauge, J. G. (1971). Pressure-induced dissociation of ribosomes during ultracentrifugation. FEBS Lett 17, 168-172. 
Hoover, D. G., Metrick, C., Papineau, A. M., Farkas, D. F. \& Knorr, D. (1989). Biological effects of high hydrostatic pressure on food microorganisms. Food Technol 43, 99-107.

Hurst, A. (1984). Revival of vegetative bacteria after sublethal heating. In The Revival of Injured Microbes, pp. 77-102. Edited by M. H. E. Andrew \& A. D. Russell. London: Academic Press.

Hurst, A. \& Hughes, A. (1978). Stability of ribosomes of Staphylococcus aureus S6 sublethally heated in different buffers. I Bacteriol 133, 564-568.

Jaenicke, R., Bernhardt, G., Lüdemann, H. G. \& Stetter, K. O. (1988). Pressure-induced alterations in the protein pattern of the thermophilic archebacterium Methanococcus thermolithotrophicus. Appl Environ Microbiol 54, 2375-2380.

Jannasch, H. W. \& Taylor, C. D. (1984). Deep-sea microbiology. Annu Rev Microbiol 38, 487-514.

Johnston, D. E. (1994). High pressure - a new dimension to food processing. Chem Ind 13, 499-501.

Kato, C., Sato, T., Smorawinska, M. \& Horikoshi, K. (1994). High pressure conditions stimulate expression of chloramphenicol acetyltransferase regulated by the lac promoter in Escherichia coli. FEMS Microbiol Lett 122, 91-96.

Landau, J. (1967). Induction, transcription and translation in Escherichia coli: a hydrostatic pressure study. Biochim Biophys Acta 149, 506-512.

Lepock, J. R., Frey, H. E. \& Inniss, W. E. (1990). Thermal analysis of bacteria by differential scanning calorimetry: relationship of protein denaturation in situ to maximum growth temperature. Biochim Biophys Acta 1055, 19-26.

Mackey, B. M., Miles, C. A., Parsons, S. E. \& Seymore, D. A. (1991). Thermal denaturation of whole cells and cell components of Escherichia coli examined by differential scanning calorimetry. $J$ Gen Microbiol 137, 2361-2374.

Mackey, B. M., Miles, C. A., Seymore, D. A. \& Parsons, S. E. (1993). Thermal denaturation and loss of viability in Escherichia coli and Bacillus stearothermophilus. Lett Appl Microbiol 16, 56-58.

Mackey, B. M., Forestière, K., Isaacs, N. S., Stenning, R. \& Brooker, B. (1994). The effect of high hydrostatic pressure on Salmonella thompson and Listeria monocytogenes examined by electron microscopy. Lett Appl Microbiol 19, 429-432.

Miles, C. A., Mackey, B. M. \& Parsons, S. E. (1986). Differential scanning calorimetry of bacteria. J Gen Microbiol 132, 939-952.

Mohácsi-Farkas, Cs., Farkas, J. \& Simon, A. (1994). Thermal denaturation of bacterial cells examined by differential scanning calorimetry. Acta Aliment 23, 157-168.

Nakashima, K., Horikoshi, K. \& Mizuno, T. (1995). Effect of hydrostatic pressure on the synthesis of outer membrane proteins in Escherichia coli. Biosci Biotechnol Biochem 59, 130-132.

Nilsson, M., Birnbaum, S. \& Wahlund, K. G. (1996). Determination of relative amounts of ribosome and subunits of Escherichia coli using asymmetrical flow field-flow fractionation. $J$ Biochem Biophys Methods 33, 9-23.

Nilsson, M., Bülow, L. \& Wahlund, K. G. (1997). Use of field-flow fractionation for the rapid quantitation of ribosome and ribosome subunits in Escherichia coli at different protein production conditions. Biotechnol Bioeng 54, 461-467.

Noll, M. \& Noll, H. (1976). Structural dynamics of bacterial ribosomes. V. Magnesium-dependent dissociation of tight couples into subunits: measurement of dissociation constants and exchange rates. $J \mathrm{Mol}$ Biol 105, 111-130.

Schultz, E., Lüdemann, H.-D. \& Jaenicke, R. (1976). High pressure equilibrium studies on the dissociation-association of $E$. coli ribosomes. FEBS Lett 64, 40-43.

Schwartz, J. R. \& Landau, J. V. (1972). Inhibition of cell-free protein synthesis by hydrostatic pressure. J Bacteriol 112, 1222-1227.

Shigehisa, T., Ohmori, T., Saito, A., Taji, S. \& Hayashi, R. (1991). Effects of high hydrostatic pressure on characteristics of port slurries and inactivation of microorganisms associated with meat and meat products. Int J Food Microbiol 12, 207-216.

Smith, W., Pope, D. \& Landau, J. V. (1975). Role of bacterial ribosome subunits in barotolerance. J Bacteriol 124, 582-584.

Spirin, A. S. (1971). On the equilibrium of the associationdissociation reaction of ribosomal subparticles and on the existence of the so-called ' $60 \mathrm{~S}$ intermediate' ('swollen 70S') during centrifugation of the equilibrium mixture. FEBS Lett 14, 349-353.

Stephens, P. J. \& Jones, M. V. (1993). Reduced ribosomal thermal denaturation in Listeria monocytogenes following osmotic and heat shocks. FEMS Microbiol Lett 106, 177-182.

Tolker-Nielsen, T. \& Molin, S. (1996). Role of ribosome degradation in the death of heat-stressed Salmonella typhimurium. FEMS Microbiol Lett 142, 155-160.

Tomlins, R. I. \& Ordal, Z. J. (1976). Thermal injury and inactivation in vegetative bacteria. In Inhibition and Inactivation of Vegetative Microbes, pp. 153-190. Edited by F. A. Skinner \& W. B. Hugo. London: Academic Press.

VanBogelen, R. A. \& Neidhardt, F. C. (1990). Ribosomes as sensors of heat and cold shock in Escherichia coli. Proc Natl Acad Sci USA 87, 5589-5593.

Welch, T. J., Farewell, A., Neidhardt, F. C. \& Bartlett, D. H. (1993). Stress response of Escherichia coli to elevated hydrostatic pressure. J Bacteriol 175, 7170-7177.

Yayanos, A. A. (1995). Microbiology to 10,500 meters in the deep sea. Annu Rev Microbiol 49, 777-805.

Received 10 September 1998; revised 6 November 1998; accepted 12 November 1998. 